\title{
DISKRIMINASI RAS DALAM FILM THE HELP KARYA TATE TAYLOR (Kajian Feminisme)
}

\author{
Fanny Ariesta, Liliana Muliastuti ${ }^{1}$ \\ Pascasarjana Pendidikan Bahasa, Universitas Negeri Jakarta, \\ Jl. Rawamangun muka, Jakarta Timur 13220 \\ Email : ariestafanny@gmail.com
}

\begin{abstract}
Abstrak
Penelitian ini bertujuan untuk meneliti dan menjelaskan unsur-unsur intrinsik dan diskriminasi ras yang terdapat dalam film The Help karya Tate Taylor berdasarkan kajian feminisme. Diskriminasi ras dikaji berdasarkan teori womanisme dari Layli Philips. Penelitian ini merupakan penelitian kualitatif dengan menggunakan metode analisis isi. Temuan dalam penelilitian ini mencakup (1) unsur fiksi yakni unsur intrinsik dalam film The Help karya Tate Taylor meliputi penokohan, tema, alur dan latar (2) usaha-usaha yang dilakukan perempuan dalam menghadapi diskriminasi ras digambarkan dalam film The Help karya Tate Taylor berdasarkan unsur-unsur fiksi (3) bentuk-bentuk perilaku diskriminasi ras yang digambarkan dalam film The Help karya Tate Taylor berdasarkan unsur-unsur fiksi. Teori womanisme yang digunakan untuk mengkaji film The Help, melawan tiga bentuk penindasan yakni penindasan ras, kelas sosial dan gender. Konsep anti oppressionist digunakan untuk menganalisis usaha-usaha yang dilakukan perempuan kulit hitam untuk berjuang melawan penindasan. Hasil dari penelitian ini diharapkan dapat berguna dalam proses pembelajaran bahasa dan sastra, khususnya kajian feminisme sehingga dapat meningkatkan kemampuan peserta didik maupun pembaca dalam memahami sastra.
\end{abstract}

Kata kunci : anti oppresionist,diskriminasi ras,feminisme,film,womanisme.

\begin{abstract}
This research is aimed to analyze and explain intrinsic elements and racial discrimination in The Help movie by Tate Taylor based on the study of feminism. Racial discrimination is examined based on theory of womanism by Layli Philips. This research was qaulitative research which used content analysis method. The findings of this research are included (1) to describe fiction elements (intrinsic elements) in The Help movie directed by Tate Taylor as follows, character, theme, plot and setting (2) to analyze black women's struggles when faced racial discrimination in The Help movie based on fiction elements (3) to reveal forms of racial discrimination in The Help movie based on fiction elements. The theory of womanism is used to analyze three kind of oppression as follows : racial discrimination, social class and gender in The Help movie. The concept of anti oppressionist is used to analyze black women's struggle in facing oppression. The result of this research is expected to be useful in the process of learning language and literature. It especially focused on the theory of feminism in order to improve the ability of learners and readers in understanding literature.
\end{abstract}

keywords : anti oppressionist, feminism, film, racial discrimination, womanism.

\footnotetext{
${ }^{1}$ Pembimbing
} 


\section{PENDAHULUAN}

Pembelajaran sastra merupakan salah satu hal penting untuk meningkatkan pemahaman dan minat siswa terhadap dunia bahasa dan sastra. Pembelajaran sastra di sekolah dapat digunakan untuk mentransformasi nilai kemanusiaan kepada peserta didik. Salah satu nilai-nilai kemanusiaan dapat diperoleh dari karya sastra. Karya sastra diyakini mampu mengubah cara berpikir manusia dengan cara menghadirkan cerita-cerita berdasarkan realitas sosial dan menginspirasi penikmatnya.

Karya sastra yang dikemas dengan menarik dapat menjadi pembelajaran yang menarik pula untuk peserta didik. Hal tersebut merupakan upaya untuk membangun manusia yang berkarakter, memacu kreativitas dalam berkarya, dan meningkatkan kemampuan intelektual. Salah satu karya sastra yang dapat dijadikan media ajar adalah melalui film. Sejalan dengan program Kemendikbud tahun 2017 yaitu Pendidikan Penguatan Karakter (PPK) yang akan diimplementasikan pada 9.830 sekolah negeri dan swasta di Indonesia. Kemendikbud menanamkan pendidikan karakter melalui sastra. Menurut Suwardi didalam Erik Purnama (2016 :1) selaku ketua umum Hiski (Himpunan Sarjana Kesusasteraan Indonesia) mengatakan bahwa prinsip sastra adalah memanusiakan manusia. Sastra bertujuan untuk mengubah tingkah laku manusia menjadi lebih berbudaya, humanis, serta sadar diri. Karena itu, pengajaran sastra diharapkan dapat membuat halus hati manusia.

Salah satu nilai penting yang bisa digali dalam karya sastra yakni pemahaman terhadap keberagaman dalam kehidupan sosial. Keberagaman merupakan fakta sosial yang menuntut setiap orang untuk menghargai perbedaan.
Namun, masih banyak yang mempermasalahkan perbedaan tersebut sehingga dapat berujung memecahbelahkan kedamaian dan keutuhan dalam suatu negara. Manusia seharusnya bisa menerima perbedaanperbedaan yang ada dan saling menghargai antarsesama, tanpa melakukan intimidasi ataupun diskriminasi dalam kehidupan bermasyarakat.

Diskriminasi ras merupakan salah satu dari isu sosial yang hingga saat ini masih menjadi perdebatan dalam kehidupan sosial. Adapun isu ini disebabkan oleh tidak diakui atau tidak diterimanya ragam perbedaan dari tampilan fisik pada seperti warna kulit, warna rambut, bentuk tubuh, dan unsur biologis lainnya. Pada kelompok tertentu, perbedaan unsur-unsur tersebut dapat menimbulkan perbedaan pola pikir dalam bermasyarakat. Perbedaan pola pikir tersebutlah, yang menimbulkan polemik bahkan sampai terjadinya penindasan terhadap ras atau golongan tertentu. Menurut Theodorson \&Theodorson yang dikutip Fulthoni (2009:5), diskriminasi adalah perlakuan yang tidak adil dan tidak seimbang yang dilakukan untuk membedakan terhadap perorangan atau kelompok, berdasarkan sesuatu yang biasanya bersifat kategorial, atribut- atribut khas, seperti berdasarkan ras, kesukubangsaan, agama atau keanggotaan. Hal ini didukung oleh Fredman (2001:10) mengatakan bahwa rasisme bukan tentang karakteristik objektif, tetapi mengenai hubungan antara dominasi dan subordinasi, bentuk kebencian terhadap "ras lain" untuk membela "keegoisan diri", hal ini dilakukan dan dilegitimasi dengan melihat citra dari ras lain sebagai bagian dari inferior, menjijikkan bahkan tidak manusiawi.

Melihat fakta diskriminasi ras seperti yang terjadi di Indonesia, Mely.G Tan 
(2008:276) mengatakan bahwa puncak kerusuhan terdahsyat di Jakarta pada pertengahan mei 1998, ditujukan pada orang etnis Tionghoa dengan serangan kepada tempat bisnis, pertokoan dan pemukiman yang kebanyakan dimiliki orang Tionghoa. Selanjutnya, diskriminasi ras dibelahan dunia lainnya di negara belahan Eropa. Anup Shah (2016:1) mengatakan bahwa pada tahun 2010, kekerasan massal dialami para pekerja pertanian Afrika yang bekerja di Itali selatan. Kejadian tersebut telah memakan korban luka-luka hingga 70 orang, sehingga mengakibatkan polisi harus mengevakuasi lebih dari 300 pekerja dari daerah tersebut. Para pekerja tersebut menjadi sasaran eksploitasi sebagai pemetik buah dengan upah yang sangat minim dan hidup dalam kesulitan. Untuk mengatasi berbagai masalah pelik tersebut dibutuhkan upaya-upaya nyata dan perjuangan dalam menyelesaikan isu rasisme. Banyak disiplin ilmu yang membahas masalah diskriminasi ras, termasuk juga dalam sastra. Salah satu karya sastra yang mengangkat tema rasisme yakni film The Help karya Tate Taylor. The Help merupakan film yang menarik untuk diteliti, karena menggambarkan persoalan-persoalan realitas sosial. Salah satu contohnya adalah tentang bentuk-bentuk perilaku rasisme dan usaha-usaha untuk memperjuangkan hak yang dilakukan kaum perempuan kulit hitam dalam menghadapi diskriminasi.

Dalam penelitian ini, peneliti menggunakan teori feminisme dan mengkaji lebih dalam usaha-usaha perlawanan yang dilakukan perempuan kulit hitam dengan menggunakan teori womanisme. Peneliti menggunakan film The Help karya Tate Taylor sebagai objek penilitian. Menurut Bhasin dan Khan, feminisme adalah kesadaran akan adanya ketidakadilan yang sistematis pada perempuan dalam berbagai macam sektor kehidupan, serta upaya-upaya secara sadar oleh perempuan maupun laki-laki untuk mengubah keadaan tersebut. Selanjutnya, Layli Philips (2006:xxi)mengatakan bahwa Hubungan womanisme dengan gender yaitu fakta-fakta secara historis berasal dari acuan ras/kelas sosial/gender dari kaum perempuan kulit hitam yang berfungsi sebagai titik mula untuk bersuara secara bebas dan mandiri. Hal tersebut relevan dengan konsep anti oppressionist yakni sebuah perlawanan dari berbagai macam penindasan, ketidakdetaraan dan ketidakadilan. Sejalan dengan anti oppressionist, konsep "everyday resistance" yang diciptakan oleh James C. Scott dengan melakukan perlawanan secara "halus", dengan verbal ataupun nonverbal, tidak begitu dramatis dan tidak terlihat seperti pemberontakan yang menimbukan huru hara, demonstrasi, revolusi, hingga perang saudara(civil war). Scott ( 1989:54) mengatakan "By subordinate groups is the pervasive use of disguise. The disguise is of two main types, with many intermediate possibilities. First and most common is the concealment or anonymity of the resister."

Berdasarkan hal-hal yang telah dipaparkan, womanisme menitik beratkan pada tiga aspek yaitu pada pengalaman perempuan kulit hitam serta perlawananya terhadap diskriminasi ras, kelas sosial, dan gender. Hal tersebut merupakan masalah sosial yang dialami perempuan kulit hitam yang tidak terbantahkan oleh fakta sejarah. Hasil dari penelitian ini diharapkan dapat berguna dalam proses pembelajaran bahasa dan sastra, khususnya kajian feminisme sehingga dapat meningkatkan kemampuan peserta didik maupun pembaca dalam memahami sastra.

\section{METODE PENELITIAN}

Dalam penelitian ini, peneliti menggunakan metode analisis isi. Pendekatan yang digunakan dalam penelitian ini adalah pendekatan kualitatif yakni bertujuan untuk membuat deskripsi 
gambaran atau lukisan secara sistematis, faktual dan akurat mengenai fakta, sifat serta hubungan antar fenomena yang diselidiki secara kualitatif. Adapun teknik pengumpulan data yang sesuai dengan penelitian ini yakni nalisis dokumen.Dalam penelitian ini, peneliti menghimpun dan menganalisis data-data mengenai unsur-unsur fiksi yang meliputi penokohan, tema, alur serta latar dan diskriminasi ras yang digambarkan dalam film The Help karya Tate Taylor ditinjau dari kajian feminisme, khususnya teori womanisme menurut Layli Philips.

\section{HASIL PENELITIAN DAN PEMBAHASAN}

1. Unsur-unsur fiksi dalam film meliputi tokoh, tema, alur dan latar yang digambarkan dalam film The Help karya Tate Taylor

Dalam penelitian ini, peneliti membahas dan mendeskripsikan unsur fiksi yakni penokohan, tema, alur dan latar yang terdapat dalam film The Help karya Tate Taylor berdasarkan data yang diperoleh dan berlandaskan dengan konsep-konsep yang relevan yakni sebagai berikut :

a. Penokohan

Dalam film The Help karya Tate Taylor , peneliti menemukan empat karakter yang memiliki peran penting untuk membangun cerita dalam film tersebut yakni Eugenia Skeeter Phelan, Aibileen Clark, Hilly Holbrook dan Minny Jackson. Tokoh Eugenia Skeeter Phelan digambarkan sebagai tokoh perempuan kulit putih yang mandiri, cerdas dan berani. Tokoh Aibileen Clark digambarkan sebagai pembantu kulit hitam yang penyayang, berani, pintar menulis dan religius. Tokoh Hilly Holbrook digambarkan sebagai karakter antagonis yang suka mengadu domba dan rasis. Serta, tokoh Minny Jackson adalah sosok yang berani, pintar memasak dan setia kawan. b. Tema

Dalam film The Help terdapat tema utama yakni isu diskriminasi ras.Selain itu, dalam film tersebut diperoleh tiga tema pendukung yaitu rasisme, perjuangan melawan rasisme dan perbedaan kelas sosial.

c. Alur

Alur yang digunakan dalam film The Help karya Tate Taylor yakni alur maju mundur.

\section{d. Latar}

Dalam film The Help karya Tate Taylor terdapat tiga latar yakni latar tempat, latar waktu dan latar sosial budaya. Latar tempat dalam film ini terjadi di kota Jackson. Jackson merupakan ibu kota negara bagian Mississipi. Ada beberapa tempat yang digambarkan dalam film tersebut yakni rumah Skeeter, rumah Aibileen, rumah Hilly Holbrook, rumah Minny Jackson, rumah Celia foote, Kantor penerbitan "The Jackson Journal" dan "Harper and Row Newyork", The Junior League of Jackson, dan beberapa tempat umum di Jackson ( tempat penjemputan bis khusus pekerja kaum kulit hitam, penjara, pasar swalayan, gereja). Selanjutnya, latar waktu yang terdapat dalam film The Help karya Tate Taylor yakni sore hari, pagi hari, malam hari, acara baby shower Elizabeth, Bridge club day, 17 Desember 1963, pemerintahan Kennedy.

Latar sosial budaya dalam film The Help dapat dilihat dari perilaku,kebiasaan, cara berpikir, dan penamaan dalam kehidupan sosial masyarakat di Jackson, Mississipi. Perilaku yang mencerminkan keadaan sosial pada film ini adalah perilaku rasisme. Mengenai kebiasaan masyarakat kulit putih di Jackson, terutama untuk wanita dan ibu-ibu muda yang memiliki status sosial kelas atas yakni melakukan perkumpulan pada suatu komunitas dan bergaya hidup sosialita. Cara berpikir perempuan kulit putih yakni 
mereka harus menikah diusia muda, memiliki suami mapan, mempunyai anak namun pada kenyataannya untuk mengurus urusan rumah tangga mereka membutuhkan bantuan dari black maids. Penamaan juga menjadi salah satu hasil dari latar sosial budaya. kaum kulit putih memanggil kaum kulit hitam dengan sebutan nigger, nigga atau nigra.

\section{Usaha-Usaha yang Dilakukan Perempuan dalam Menghadapi Diskriminasi Ras Digambarkan dalam Film The Help Berdasarkan Unsur- Unsur Fiksi.}

Dalam film The Help karya Tate Taylor digambarkan perjuangan dan perlawanan melalui tokoh-tokoh perempuan kulit hitam untuk mendapatkan keadilan di Amerika. Usaha-usaha tersebut dilakukan dengan dua cara yakni melawan dan membongkar, sesuai dengan konsep "anti oppressionist" dari Layli Philips (2006: xxiv) "a womanist knows oppression whe she sees it, and she is against it. She lives her life in a such way as to fight and dismantle oppression in whatever ways she can, individually or in organized with others."

Hal ini juga relevan dengan konsep "everyday resistance" yang diciptakan oleh James C. Scott sebagai bentuk perlawanan yang dapat dilakukan secara "halus", dengan verbal ataupun non verbal, tidak begitu dramatis dan tidak terlihat seperti pembenrontakan yang menimbulkan demonstrasi, revolusi, hingga perang saudara (civil war). Berdasarkan penjelasan di atas mengenai tindakan perlawanan secara langsung dan perlawanan secara tidak langsung. Kedua bentuk perlawanan tersebut dilakukan dengan cara verbal dan nonverbal, sedangkan membongkar dilakukan dengan dua cara yakni melakukan penelusuran dan membongkar rahasia.
Berikut merupakan hasil penelitian usahausaha yang dilakukan perempuan untuk menghadapi diskriminasi ras yang terdapat dalam film di bawah ini.

\section{a. Melawan}

1) Perlawanan secara langsung verbal

Perlawanan secara langsung dalam bentuk verbal merupakan sikap defensif secara langsung yang ditunjukan kepada objek yang bersangkutan melalui lisan atau verbal. Hal tersebut dapat ditunjukan pada dialog dibawah ini.

(Setting : Ruang makan rumah Hilly Holbrook. Tokoh : Minny, Hilly dan Missus Walters. Adegan pada menit 01.37.26-01.39.14.)

HILLY : Oh. Pie's as good as always, Minny.

MINNY : I'm glad you like it.

HILLY : If i take you back, i'll have to cut your pay five dollars a week.

MINNY : Take me back?

HILLY : What do you put in here that makes it taste so good?

MINNY : That good vanilla from Mexico and something else real special. No, no, no, Missus Walters. That's Miss Hilly's special pie.

HILLY : Mama can have a piece. Oh, cut her one. Go get a plate.

MINNY : EAT MY SHIT !

HILLY : What'd you say?

MINNY : I said " EAT ....MY ....SHIT!

HILLY : Have you lost your mind?

MINNY : No, ma'am. But you about to, 'cause you just did.

HILLY : Did what?

MISSUS WALTERS : Hahaha. And you didnt eat just one, you had two slices

Sikap yang dilakukan Minny terhadap Hilly relevan dengan konsep yang dijelaskan oleh James Scott bahwa perlawanan dapat dilakukan tidak hanya dengan nonverbal, namun juga dengan verbal. Perlawanan secara langsung dalam 
bentuk verbal ditandai dengan adanya sikap menentang yang ditujukan kepada pihak yang menekan dan menindas melalui ucapan atau lisan yang terdapat pada frasa "eat my shit".

2) Perlawanan Secara Langsung dalam Bentuk Nonverbal

Perlawanan secara langsung dalam bentuk nonverbal ialah sikap defensif secara langsung dengan ditujukan kepada objek yang bersangkutan melalui perbuatan-perbuatan yang bersifat fisik. Hal tersebut dapat ditunjukan dalam adegan yang diperankan tokoh Minny Jackson di bawah ini.

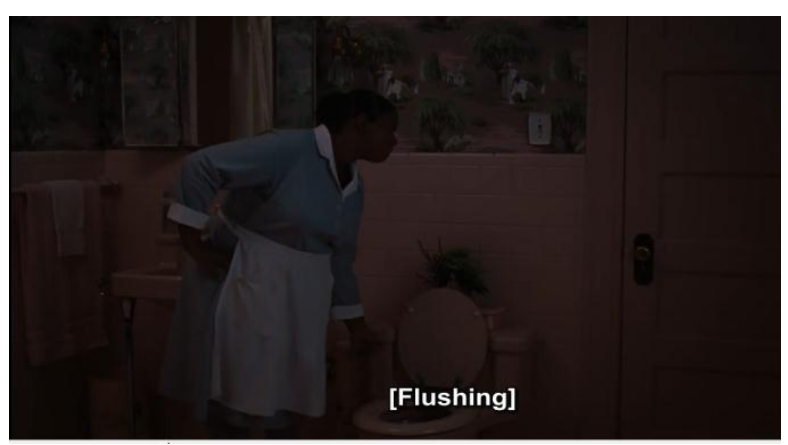

Cuplikan gambar tersebut menunjukan sikap perlawanan secara langsung nonverbal. Perlawanan yang dilakukan Minny yakni dengan menekan tombol siram pada kakus duduk yang ada pada toilet majikannya. Selain itu, pada adegan tersebut Minny sengaja membanting dengan keras tutup kakus duduk agar terdengar Hilly. Majikannya mendengar suara tersebut merasa kesal dan marah besar. Hal tersebut menunjukan sikap yang dilakukan Minny yakni perlawanan secara langsung nonverbal.

3) Perlawanan Secara Tidak Langsung dalam Bentuk Verbal

Perlawanan secara tidak langsung dalam bentuk verbal yakni terjadi apabila seseorang membicarakan orang lain di belakangnya atau secara tidak langsung. Hal tersebut dapat ditunjukan dalam adegan yang diperankan tokoh Minny Jackson dan Aibileen di bawah ini.

(Setting : ruang dapur rumah Elizabeth. Tokoh : Minny dan Aibileen. Adegan pada menit $10.16-10.23$.)

MINNY : Now she gone to putting pencil marks on my toilet paper.

AIBILEEN : Did she?

MINNY : mm..mmm. But i carry paper in from my damn house. That fool don't know

Adegan di atas menunjukan sikap perlawanan secara langsung dalam bentuk nonverbal. Hal tersebut terdapat pada frasa "carry paper" dan "that fool". Hilly menandai setiap kertas tisu toilet di rumahnya agar mengetahui jumlah kertas tisu yang terpakai. Minny merasa terintimidasi dengan sikap Hilly, sehingga ia diam-diam membawa kertas tisu toilet sendiri dari rumahnya tanpa sepengatuan Hilly. Ia juga mengolok dengan menyebut Hilly dengan panggilan "si bodoh".

4) Perlawanan Secara Tidak Langsung dalam Bentuk Nonverbal

Perlawanan secara tidak langsung dalam bentuk nonverbal yakni sikap defensif yang secara tidak langsung namun memberikan perubahan yang berdampak. Hal tersebut terdapat dalam adegan di bawah ini.

(Setting : saat wawancara untuk penulisan buku di ruang dapur rumah Aibileen. Tokoh : Aibileen dan Skeeter. Adegan pada menit 43.39-46.04.)

SKEETER :Do you want to talk about thebathroom? Or anything about MissLeefolt?

Howshe pays you or Has she ever yelledat you in front of Mae Mobley?

AIBILEEN : I thought I might write my stories down and read them 
to you. Ain't no different than writing down my prayers

SKEETER AIBILEEN :OK. Sure.

: I don't say my prayers out loud. I can get my point accross a lot better writting them down. I write an hour, sometimes two, every night. And after my prayer last night, i got some stories down, too.

\section{SKEETER : Go ahead}

\section{b. Membongkar}

1) Penelusuran

Penelusuran

"mengusut"

memiliki pengertian dan "menelaah".

Diskriminasi ras yang dialami warga kulit hitam menjadi cambuk untuk berani membuka suara dalam mengungkapkan fakta yang terjadi. Hal tersebut terdapat pada adegan di bawah ini.

(Setting : Perkarangan rumah Elizabeth. Tokoh : Aibileen dan Skeeter. Adegan pada menit 28.31)

SKEETER : Aibileen, there is something else i want to write about. I would need your help. I want to interview you....about what it is like to work as a maid.I'd like to do a book of interviews about working for white families. And we could show what it's like to work for, say...Elizabeth.

Pada frasa "to interview you" menunjukan bahwa Skeeter memiliki tujuan untuk melakukan penelusuran dengan melakukan wawancara dengan Aibileen. Hal tersebut menunjukan investigasi untuk menyingkap fakta. Ia ingin membongkar dan mengungkap fakta rasisme yang terjadi di Jackson dengan menggunakan sudut pandang pengalaman Aibileen sebagai pembantu kulit hitam yang bekerja dengan majikan kulit putih.

\section{2) Rahasia}

Kata "rahasia" dalam kamus istilah memiliki pengertian sesuatu yang sengaja disembunyikan supaya tidak diketahui orang lain atau sesuatu yang belum dapat atau sukar diketahui dan dipahami orang. Hal tersebut terdapat dalam adegan di bawah ini.

(Setting : monolog ketika Aibileen berhenti kerja dari keluarga Elizabeth. Lokasi di sekitar jala Jackson. Tokoh : Aibileen. Adegan pada menit 02.17.05 02.18.38)

AIBILEEN : Mae Mobley was my last baby. In just ten minutes, the only life $\mathrm{i}$ knew was done. God says we need to love our enemies. It hard to do. But it can start by telling the truth. No one had ever asked me what it felt like to be me. Once i told the truth about that.. i feel free. And i got to thinking all the people i know. And the thing $\mathrm{i}$ seen and done. My boy, Treelore, always said we going to have a writer in the family one day. I guess it's gonna be me.

Pada adegan di atas terdapat frasa "telling the truth" yang diucapkan Aibileen menunjukan pengertian sikap dari membongkar dan mengungkapkan suatu rahasia dan fakta nyata yang terjadi. Dengan menulis, ia mampu mencurahkan semua perasaan dan pengalamannya sehingga ia merasa bebas.

\section{3) Bentuk-Bentuk \\ Perilaku Diskriminasi Ras yang Digambarkan dalam Film The Help karya Tate Taylor Berdasarkan Unsur-Unsur Fiksi.}

Dalam film The Help karya Tate Taylor, peneliti menemukan beberapa perilaku diskriminasi yang dilakukan kaum kulit putih terhadap kaum kulit hitam, khususnya pembantu. Womanisme merupakan sebuah tombak semangat serta gerakan nyata kaum perempuan kulit hitam untuk berjuang dan melawan segala 
BAHTERA: Jurnal Pendidikan Bahasa dan Sastra, Volume 16 Nomor 2 Juli 2017

ISSN : 0853-2710

bentuk penindasan ras, kelas sosial dan gender.

a. Penindasan Ras

Diskriminasi ras merupakan pengelompokan manusia berdasarkan warna kulit yang dilakukan kaum mayoritas terhadap kaum minoritas. Hal tersebut terdapat dalam adegan di bawah ini.

(Setting : rumah Elizabeth. Tokoh : Hilly dan Skeeter. Adegan pada menit 15.48 16.18.)

HILLY : That's why I've drafted The Home Help Sanitation Initiative.

SKEETER: The what?!

HILLY : As a disease preventative bill that requires every white home to have a separate bathroom for the colored help. It's been endorsed by the white citizen's council.

SKEETER : Maybe we should just build you a bathroom outside, Hilly.

HILLY : You ought not to joke about the colored situation. I'll do whatever it takes toprotect our children.

Berdasarkan dialog di atas, frasafrasa seperti "the home help sanitation initiative", "have separate bathroom for the colored help", dan "colored situation", menunjukan adanya racial hatred dan perilaku diskriminasi terhadap colored people. Inisiatif toilet terpisah semakin membuat jarak dan perbedaan antara kaum kulit putih dan kaum kulit hitam. Sebutan seperti "colored help" dan "color situation" memberikan pengertian eksplisit bahwa diskriminasi ras terhadap kaum kulit hitam sangat jelas terjadi. b. Kelas Sosial

Penggolongan manusia berdasarkan kekayaan, pendidikan dan pekerjaan dapat menentukan status sosial seseorang. . Hal tersebut terdapat dalam film The Help pada adegan di bawah ini.

(Setting : wawancara Skeeter dan Aibileen untuk penulisan buku "The Help" di ruang dapur rumah Aibileen. Tokoh : Aibileen. Adegan pada menit 44.46 -45.02.)

AIBILEEN : My first white baby to ever look after was name Alton Carrington Speers. It was 1925, and i had just turned 14. I dropped out of school to help Mama with the bills.

Berdasarkan data literer di atas, Aibileen mengatakan "dropped out of school" yang memiliki arti "berhenti sekolah" di usia 14 tahun. Kehidupan yang keras memaksanya untuk berhenti sekolah karena tuntutan ekonomi keluarga. Pendidikan merupakan hal yang berpengaruh dalam menentukan kelas sosial seseorang. Taraf tinggi ataupun rendah pendidikan seseorang mempengaruhi jenjang kelas sosial.

\section{c. Gender}

Gender yakni hasil kesepakatan adanya perbedaan peran, fungsi serta tanggung jawab pada laki-laki dan perempuan sebagai sebuah hasil dari konstruksi sosial budaya melalui proses sosialisasi dari waktu ke waktu. Hal tersebut terdapat pada adegan di bawah ini.

(Setting : percakapan awal mula film (flashback) di ruang dapur rumah Aibileen. Tokoh : Skeeter dan Aibileen. Adegan pada menit 01.30 -01.50.)

SKEETER : And did you know as a girl, growing up, that one day you'd be a maid?

AIBILEEN : Yes, ma'am. I did. 
BAHTERA: Jurnal Pendidikan Bahasa dan Sastra, Volume 16 Nomor 2 Juli 2017

http://journal.unj.ac.id/unj/index.php/bahtera/

ISSN : 0853-2710

SKEETER

because?

AIBILEEN

\section{SKEETER}

Now, did you ever dream of being something else?

Dalam adegan tersebut, perempuan kulit hitam seperti sudah "mengetahui" nasibnya kelak akan menjadi seperti apa dan mereka merasa tidak bisa merubah keadaan tersebut yakni menjadi budak, pembantu atau buruh kelas bawah. Hal ini ditunjukan pada frasa yang diucapkan oleh Aibileen yakni "My Momma was a maid. My grandmama was a house slave."

\section{SIMPULAN DAN SARAN}

Kesimpulan yang diperoleh dari hasil analisis yakni perilaku-perilaku yang mencerminkan diskriminasi ras dalam film The Help karya Tate Taylor. Diskriminasi yang dialami oleh pembantu perempuan kulit hitam yakni penindasan ras, penindasan kelas sosial (kekayaan atau ekonomi, pendidikan dan dan penindasan gender.

Dari berbagai macam diskriminasi ras yang dialami oleh kaum kulit hitam, mereka melakukan usaha-usaha dan perjuangan dalam menghadapi diskriminasi ras dilakukan dengan dua hal yakni melawan dan membongkar. Kedua hal tersebut relevan dengan konsep antioppressionist. Anti oppression merupakan tindakan perlawanan yang harus dilakukan untuk menyikapi diskriminasi yang merugikan kaum minoritas. Dalam konsep melawan dicirikan dengan dua aspek yakni perlawanan secara langsung (verbal dan nonverbal) dan perlawanan secara tidak langsung (verbal dan nonverbal).Serta, dalam konsep membongkar dilakukan dengan dua cara yakni melakukan penelusuran dan membongkar rahasia.

\section{DAFTAR PUSTAKA}

Bhasin, Kamala \& Khan. 1995. Persoalan pokok mengenai Feminisme dan Relevansinya.Jakarta : Gramedia Pustaka Utama

\section{Fredman, Sandra. 2001. Discrimination and Human Rights : the Case of Racism. New York : Oxford University Press inc.}

Fulthoni, M A. 2009. Memahami Diskriminasi : Buku Saku Kebebasan Beragama, .Jakarta : The Indonesian Legal Resource Center.

Phillips, Layli. 2006. The Womanist Reader. Newyork : Routledge.

Putra, Erik Purnama.2016.Penguatan Pendidikan Karakter Siswa Melalui PengajaranSastra, (http://www.republ ika.co.id/berita/koran/urbana/17/01/1 6/ojvd814-penguatan-pendidikankarakter-siswa-melalui-pengajaransastra). h 1.

Scott, C James. 1989. Everyday Forms of Resistance. Copenhagen: Papers 4.

Shah, Anup. "Racism", http://www.globalissues.org/article/1 65/racism. h 1.

Tan, Mely G.2008.Etnis Tionghoa di Indo nesia.Jakarta: Yayasan Obor Indonesia.

The Help movie. 2011. Directed by Tate Taylor. 